\title{
Problematic and Alternative Solution of Mathematics Study During Covid-19 Pandemic
}

\author{
Tatik Indiyah ${ }^{1,2, *}$ \\ ${ }^{1}$ Magister Program student of Mathematic Education \\ ${ }^{1}$ Universitas Bhinneka PGRI \\ ${ }^{2}$ MA AL-Ma'arif Tulungagung \\ 1,2 Tulungagung, Indonesia \\ *tatikind@gmail.com \\ Imam Sukwatus Suja'i, Imam Sujono \\ Magister Program of Social Science Education \\ Universitas Bhinneka PGRI \\ Tulungagung, Indonesia \\ imam.sujai@stkippgritulungagung.ac.id, \\ Imam.sujono@ymail.com
}

\author{
Dian Septi Nur Afifah \\ Magister Program of Mathematic Education \\ Universitas Bhinneka PGRI \\ Tulungagung, Indonesia \\ dian.septi@stkippgritulungagung.ac.id
}

\begin{abstract}
The Covid-19 pandemic causes learning to be done online. But many teachers, students, and parents feel plenty of constraints in online learning. So, the study aims to describe the problems of mathematics and solution studies in the pandemic situation. The method used is a qualitative approach. The subject of research is an Islamic Senior High School in Indonesia. The results of these studies show problematic mathematical studies those students are less capable in independent learning and improper learning motivations during the Covid-19 pandemic. An alternative solution to the problem is a personal approach to students, scaffolding, learning media that more satisfy motivation for learning mathematics, and the application of online learning methods that correspond to students' characteristics. To do so is expected of teachers to select learning strategies to increase selfreliance and learning motivation.
\end{abstract}

Keywords-Covid-19, pandemic, problematic, solution

\section{INTRODUCTION}

Mathematics has an important role in all aspects of life, especially in improving human thinking. Mathematics learning is a process that contains two types of inseparable activities, that is learning and teaching. These two activities combine into an activity that creates interaction between students and teachers and fellow students during the learning process at school [1]. The teaching and learning process of mathematics deals with many concepts. Mathematical concepts have a relationship between one concept and another. Students consider that mathematics is a difficult subject, because of its abstract nature. Abstract mathematical concepts are arranged sequentially and tiered and special proof is needed, so that in the learning process the previous mathematical concept must be mastered because it is a prerequisite for continuing the next concept [2].

During the Covid-19 pandemic, mathematics increasingly became a problem in learning. This is because the interactions that should be created between learning and teaching, between students and teachers are limited. Face to face cannot be done, students and teachers only interact online. This makes students inevitably have to learn independently and requires them to find problem solutions. Typically, student problems tend to be many, diverse and complex and require an interdisciplinary approach to understand them adequately [3]. And for teachers, they must be extra creative and innovative in packaging this online learning. The quality of learning requires various efforts to make it happen, such as using multimedia interactive as an alternative in the learning process, especially in improving understanding of mathematical concepts [4]. Therefore, a competent mathematics teacher is needed in learning mathematics to produce quality learning [5].

Based on this background, the formulation of the problem in this study is how problems in learning mathematics and alternative solutions. The purpose of this research is to find out the problems.

\section{METHODS}

This research uses a qualitative approach. The research was conducted at Islamic Senior High School, that is MA Al Ma'arif Tulungagung, Indonesia. The research subjects were students of class X-IIS. The instruments used in this study were observation sheets, student questionnaires and interview transcripts. The research analysis was carried out by analyzing the observation sheet, analyzing the results of the student 
questionnaire and the results of the interview transcript. The results of the observation sheet and questionnaire were analyzed specifically on the problem of learning mathematics then combined with the results of the interview.

\section{RESULTS AND DISCUSSION}

Based on the results of observations, questionnaires, and interviews with mathematics students, it shows that there are problems that occur in learning mathematics during the Covid19 pandemic. The first problem in learning mathematics is understanding students against less mature mathematical concepts. This can be seen in the questionnaire results in the statement "Online learning models make it difficult to solve problems in mathematics "where as many as 12 students agree and 8 students strongly agree from 25 students. The impact is on the student's independent learning process. The low understanding of students' mathematical concepts from the previous level made it difficult to understand the material without direct teacher guidance. Most students prefer the learning process directly rather than virtual.

Based on the observation results of students' conditions in every online learning activity, many students are less able to master the material provided. Students complain a lot from every assignment given. The low mastery of students' mathematical concepts can be described in the following ways: a) poor student intelligence, b) lack of talent or not in accordance with the subject matter provided by the teacher, c) learning activities on their own awareness is still low, d) poor learning habits, that is learning with mastery of science at the rote level and not with an understanding that they can understand without memorizing.

The second problem in mathematics learning is the low motivation of students who are not good due to the existence of online games and social media on their gadgets. Especially with learning from home during a pandemic like this, students continue to hold their gadget. Most students prefer to open social media or games rather than open the material given. Some of them are just doing attendance. This can be seen from the questionnaire in points 7 and 8 , where as many as 20 students agreed and 2 students strongly agreed with the statement that they tended to use gadget for other things compared to the material. They also focus less on using gadget as learning material.

The third problem in mathematics learning is that students come from underprivileged families. This caused them difficulties with purchasing internet quotas. They have to save their quota to download learning videos, for example, which take up a larger quota. In addition, the e-learning services provided by madrasah have not been fully reached. Quota capacity is one of the factors. There are lots of complaints submitted by students to maple teachers regarding their minimal quota. There are also those who only have chat quota. However, students who have high enthusiasm for learning will look for ways to obtain material. However, students with low learning enthusiasm will be lazy and don't want to try, they prefer to give up. This requires a special approach and assertiveness from the teacher to anticipate this to happen more broadly.

Based on the results of interviews with several students, it was found that learning mathematics was boring. This has become a problem in itself. The fourth problem is learning from the teacher who tends to only work on assignments. This will make students even lazier and less motivated to learn mathematics. Because, students who are less able to learn independently will feel bored and stressed. They cannot ask directly, while there are many tasks. Most of them choose the path by cheating on their friends who have above average understanding. It is evident from each student assignment that is collected there are several students who collect the exact same assignments as their friends.

The fifth problem is that teachers are less active in learning. The teacher with his busy life making him less active. Because the online process, made him delay delivering material to students. Because in online learning the teacher has to make material, it is different from face-to-face. So that it makes students less in receiving scheduled lessons. The fifth problem is obtained from observations of students by conducting interviews. They feel that they often get assignments from several teachers.

Based on the research results described above, there are solutions to the four problems found during the research. The solution for the first mathematics is a poor understanding of mathematical concepts, the teacher should have provided more scaffolding even though it was online. For example, with personal support through chat or communication with parents of students. Scaffolding aims to provide assistance to students when they encounter difficulties in learning process. For example, with personal support through chat or communication with parents of students. Scaffolding aims to provide assistance to students when they encounter difficulties in learning. This is in accordance with Khatimah's opinion that scaffolding can handle students' thinking obstacles in solving problems [6].

Hanum [7] explaining that even the existence of e-learning as a learning medium adds to student enthusiasm and provides new experiences to students. However, why students are not motivated to be more enthusiastic in learning, as explained by Dumont [8] that problems in learning can be divided into two, namely learning disabilities that lie in the cognitive development of these students and the cause of learning difficulties outside the child or other problems in students. The solution to the second problem is student motivation that is not good, namely by giving the teacher a personal approach, providing guidance and a psychological approach to students so that they are more enthusiastic in participating in mathematics learning. A good influence in learning by using a personal analogy approach on student learning independence [9].

The quality of learning requires various efforts to make it happen. These efforts are related to the various components involved in learning [10]. Various supporting efforts need to 
exist to help achieve a good quality of learning, not only from the student factor, the teacher also plays an important role in improving the quality of good teaching and learning. The solution to the third problem is how teachers can find other alternatives to help students' problems. For example, if the learning model in the form of video is not maximally accessible to students, other forms of material can be provided. If e-learning is not optimal, it can be added with the use of the social media application which is lighter in absorbing data.

The solution to the fourth problem is that teachers have to rack their brains more, and not only patent books. Innovations in learning must be created. Even though using online the learning process should not make students bored or lazy. There are so many methods that teachers can use to do online learning. In addition, teachers must be good at choosing suitable learning media in delivering Mathematics subject matter. The use of multimedia learning that can be sent easily to students as express. In addition, the use of inappropriate methods in conveying material can make the teaching and learning process less effective. The fifth problematic solution is that the monitoring of the school curriculum must be tighter and make more assertiveness to less active teachers. Making a performance report every time learning takes place accompanied by physical evidence and sanctions will make teachers more serious in teaching during the Covid-19 pandemic.

Teachers should pay attention to various kinds of problems that exist in their students and themselves and look for solutions. If the problem is related to concept mastery, the teacher should be able to provide scaffolding. If the problem is related to motivation, then the teacher should provide psychological guidance and approaches. If the problem is related to the learning process, then the teacher should look for a learning process that is in accordance with the material being taught. then the teacher should be able to provide scaffolding. If the problem is related to motivation, then the teacher should provide psychological guidance and approaches. If the problem is related to the learning process, then the teacher should look for a learning process that is in accordance with the material being taught. then the teacher should be able to provide scaffolding. If the problem is related to motivation, then the teacher should provide psychological guidance and approaches. If the problem is related to the learning process, then the teacher should look for a learning process that is in accordance with the material being taught.

\section{CONCLUSION}

The problems of learning mathematics are 1) students 'lack of understanding of immature mathematical concepts, 2) poor learning motivation, many students who have low motivation in learning mathematics, 3) The economic condition of the students' families less, 4) teachers who are less innovative in the learning process, (5) teachers who are less active in prioritizing their students in online learning, and (6) lack of student discipline.

The solutions to the problems according to the results of the study were 1) scaffoldings, 2) the teacher gave a personal approach, 3) The use of learning media, 4) the teacher must be competent, innovative and creative in the learning process online, 5) participation of all school components, and 6) teachers are more active in monitoring students both personally and in coordination with parents.

\section{REFERENCES}

[1] A. Sahrudin, "Implementasi Strategi Pembelajaran Discovery untuk Meningkatkan Kemampuan Pemecahan Masalah Matematis dan Motivasi Belajar Siswa SMA,” J. Pendidik. Unsika, vol. 2, no. 1, pp. 112,2014 .

[2] M. Graciella and E. Suwangsih, "Penerapan Pendekatan Matematika Realistik Untuk Meningkatkan Kemampuan Representasi Matematis Siswa," Metod. Didakt., vol. 10, no. 2, pp. 27-36, 2016.

[3] T. Sriwahyuni, R. Maya, and R. Amelia, "Jurnal Kajian Pembelajaran Matematika,” J. Pendidik., vol. 3, no. April, pp. 18-23, 2019.

[4] D. Novitasari, "Pengaruh Penggunaan Multimedia Interaktif Terhadap Kemampuan Pemahaman Konsep Matematis Siswa," FIBONACCI J. Pendidik. Mat. dan Mat., vol. 2, pp. 8, 2016

[5] R.K. Sari, "Analisis Problematika Pembelajaran Matematika Di Sekolah Menengah Pertama Dan Solusi Alternatifnya," Prism. J. Pendidik. dan Ris. Mat., vol. 2, no. 1, pp. 23-32, 2019.

[6] H.S. Khatimah and K. Cholis, "Pemberian Scaffolding untuk Mengatasi Hambatan Berpikir Siswa dalam Memecahkan Masalah Aljabar,”JKPM J. Kaji. Pembelajaran Mat., pp. 36-45, 2017.

[7] N.S. Hanum, "Keefetifan e-learning sebagai media pembelajaran (studi evaluasi model pembelajaran e-learning SMK Telkom Sandhy Putra Purwokerto),” J. Pendidik. Vokasi, pp. 90-120, 2013.

[8] J.J. Dumont, "Theorie en Model [learning Disabilities. Part 1: Theory anda Model]," Rotterdam Lemn., 1994.

[9] J. Podomi, "Pengaruh Pendekatan Analogi Personal terhadap Prestasi, Penalaran, dan Kemandirian Siswa Materi Dimensi Dua di SMK.,' Pythagoras J. Pendidik. Mat., pp. 61-70, 2015.

[10] H. Hikmawati, "Pengaruh Penggunaan Media Pembelajaran Dan Gaya Kognitif Terhadap Hasil Belajar Matematika Siswa Kelas VIII Madrasah Tsanawiyah,” Tekno-Pedagogi, vol. 3, 2013. 